\title{
The impact of xenophobia-Afrophobia on the informal economy in Durban CBD, South Africa
}

\author{
$N T$ SHISHONGA
}

\begin{abstract}
The renewed incidents of xenophobia, which engulfed South Africa, dented this country's image, continentally and internationally. These occurrences invoke an unresolved question, thus: Can xenophobic attacks be attributed to tighter or discriminatory immigration policies or are people caught in quandary for socio-economic survival? Similarly to the pogroms in Poland against Jews, xenophobia left fatal scars, not only amongst Africans and nonAfricans, and has affected the informal economy negatively. This article explores the impact of xenophobia on the operations of the informal economy on which the poor depend for socio-economic survival. For the most part of April-May 2015, the streets of Durban were deserted because of the xenophobic attacks on non-South African businesses, particularly those owned by Africans from different parts of the continent. Fear was planted in the city of Durban, which in turn led to the decline in economic activity, both formal and informal sectors, with the later bearing the most brunt. The city was turned into a battle field whereby Afro-hatred was perpetuated with the intention of causing bodily harm and making deportation threats. Nationals from other African countries, mainly Nigerians, Somalis, Malawians, Zimbabweans, Mozambicans, Ethiopians and Congolese were accused of taking jobs meant for locals and suffocating their businesses as well as taking their women. In fear of their lives, non-South Africans were forced to close their businesses and to go into hiding. This article argues that the impact of xenophobia is a double-edged sword and has farreaching implications for both South Africans and non-South Africans as the local city dwellers depend on the services provided by informal businesses. The article uses both primary and secondary data. The empirical data was extracted mainly from the street traders and hawkers eking a living in the informal sector.
\end{abstract}

Keywords: Xenophobia-Afrophobia, South Africans, non-South Africans, Informal Economy, Durban CBD

\section{Introduction}

Historically, xenophobia has become a world-wide phenomenon that is orchestrated by various factors, mainly associated with social and economic conditions and circumstances, both locally and nationally. The spread of xenophobic and/or Afrophobic attacks directed at non-South Africans by South Africans have been documented in the media since the

\footnotetext{
${ }^{1}$ School of Social Work \& Community Development, University of KwaZulu-Natal, Durban, 4041, South Africa, e-mail: tshishonga@ukzn.ac.za
} 
democratic dispensation. Akinola (2014: 56) argues that in South Africa xenophobia is not a new phenomenon; instead, it is the extension of other forms of violence and intolerance. Various push and pull forces are at play as contributors in fuelling the psychological and physical abuses on non-South Africans from the other African nations in the continent. While most African nations attained their political freedom in the immediate post-1060s period, socio-economic development lagged behind with poverty, unemployment and inequalities on the rise. These challenges are famously known as "evil triplets" or "social evils" (Terreblanche, 2012: 101). This was reasserted by Ramphele (2008: 21) who argues that many African countries, though politically free, continue to suffer from inadequate economic reforms to underpin sustainable socio-economic development. This gloomy situation is further aggravated by autocratic governance systems which are notorious for displacing African citizens through civil wars that dislocate nationals from their land-of-birth sources of livelihoods. Unless the economic and political situation improves, Oucho (2006: 57) points out, xenophobia and unfavourable policies against foreigners would persist. In the present era, poor leadership ironically underpinned by democratic values and principles, has seen people being victims of democracy deficit and greed. The notion of democracy deficit depicts the lack of political engagement and participation by the public whereby people resort to opting out of politics (Crowther \& Martin, 2005: 213). Consequently, in fear of their lives, citizens flee their homeland countries and seek refuge in African neighbouring states, with Europe as the final destination of the aspirations of the majority (Musuva, 2014: 383). Post-1994 South Africa saw the influx of immigrants, including those displaced due to political instability as well as economic hardships. Additionally, Akinola (2014: 59) confirms that South Africa also accommodates the largest number of asylum-seekers in the world. Thus, the scramble for scarce resources and job opportunities between South Africans and non-South Africans did not only fuel tensions but it ultimately led to xenophobia and xenophobic attacks aimed at causing bodily harm. It could be argued that this situation was further perpetuated by political illiteracy on the part of South Africans with regard to African politics, including the decisive role played by other African nations in the liberation of South Africa. Among the ruling elite, denialism coupled with political illiteracy manifest itself through the adoption of immigration policies which instead of easing the tension, they aggravated them through exclusion. The attitude displayed by the law enforcement agencies such as police rubbed salt onto the open wounds with fatal incidents such as the one where a Mozambican national, Ernesto Alfabeto Nhamuave, who fell victim to xenophobic burning on 18 May 2008 (Peberdy, 2009: 138). In an attempt to present a racism perspective to South African xenophobia against African immigrants, Bekker (2010: 136), Mngxitama (2008: 195), Evert (2011: 7) and Matsinhe (2011: 298) describe the phenomenon as "negrophobia or Afrophobia”.

It is against this background that this article explores the impact of xenophobia or Afrophobia on the operations of the informal economy on which the poor locals and African immigrants depend on for socio-economic survival. In April-May 2015, the streets of Durban were deserted because of xenophobic attacks on non-South African businesses, particularly those owned by Africans from different parts of the continent. Fear was planted in the city of Durban, which led to the decline in economic activities, both formal and informal sectors, with the latter bearing the most brunt. The city was turned into a battle field whereby Afro-hatred was perpetuated with the intention of causing bodily harm and making deportation threats. Nationals from other African countries, mainly Nigerians, Somalis, Malawians, Zimbabweans, Mozambicans, Ethiopians, Congolese and so on, were accused of taking jobs meant for locals and suffocating their businesses as well as taking their 
women. In fear of their lives, non-South Africans were forced to close their businesses and to go into hiding. The renewed incidents of xenophobia in South Africa has dented this country's image, continentally and internationally. Uncomfortable questions should be asked, thus: Can one attribute xenophobic attacks on the tighter or discriminatory immigration policies or are people caught in quandary for socio-economic survival? The research from which this article is drawn found that xenophobic attacks have implications beyond economic insecurity because they inflict social and psychological scares and trauma among non-South Africans. Similarly to the rest of the country, the Durban CBD experienced social dislocation with negative impact especially in weakening business networks coupled with loss of financial returns on the part of foreigners. Thus, the outbreak of xenophobic attacks between AprilMay 2015 saw foreign nations going into hiding, leaving their businesses unattended. Conclusively, the failure of the political economy to live up to democratic dispensation expectations resulted in irresponsible and indecisive leadership aggravated by the decline of the neo-liberal economic system.

\section{Conceptualising xenophobia or Afrophobia}

In the social and political sciences, the notion of xenophobia is often attached to the extreme dislike or hatred directed to those who are not citizens of a country; that is, the dislike or hatred of one's nationality by the other (Ramphele, 2008; Sichone, 2008; Akinola, 2014). From a human rights perspective, this deep dislike of non-nationals by nationals of a recipient state, including its manifestation, is abusive violation that is unconstitutional (South African Human Rights Commission, 1998). Wicker (2001 cited in Sichone, 2008: 257) defines xenophobia as "one among several possible forms of reaction generated by anomic situation in the societies of modern states". In this context, South Africa is cited as one such good candidate for society in a condition of anomie. Central to the escalation of xenophobia is the individual vulnerability to economic and political deprivation and underdevelopment. This in turn breeds unemployment, low income and declining standards of living (Akinola, 2014: 57). Nyamjoh (2006: 49) argues that xenophobia in South Africa is not generally directed at all people perceived to be foreign nationals but it is Africanised as Afrophobia with black African foreigners being the exclusive target for xenophobic attacks and violence.

In South Africa for instance, xenophobia variably manifests itself through tribalism and ethnic superiority, racism and sexism pathologies (Moosa, 2008). According to Landau (2005: 4), xenophobia takes forms such as "discriminatory attitudes towards non-nationals" whereas Musuva (2014: 382) notes that xenophobia takes place within the context of crime, poverty, inequality and unemployment. The apartheid system of divide and rule has through the years planted seeds of hatred within the and between tribal groups, which has now reached maturation through xenophobia. The notion of xenophobia has its roots from Greek-xeno meaning foreign and phobos which connotes fear (Petkou, 2005: 116). While xenophobia is reflective of the general fear or hatred, Afrophobia is Afro-hatred mainly directed at immigrants of African nationalities. From this insight, xenophobia has to do with fear or hatred of the other. In addition, those who suffer from xenophobia are crippled with enormous fear or hatred of a stranger or foreigner, described in a derogatory term, "makwerekwere". In the context of South Africa, xenophobia could be likened to an illness or virus that will continue to spread, unless it is addressed. The Southern African Migration Project on Xenophobia (2004) revealed that most South Africans preferred the government to get tough on migrants and refugees. Southern African Migration Project also shared light 
by highlighting that xenophobia is further exacerbated through misinformation and widespread suspicion that refugees are not genuine and that they are an economic threat and that they steal rather than create jobs as well spread diseases and epidemics such as cholera and HIV/AIDS. For example, in 2008, xenophobic attacks had fatal and negative effects leaving 62 people dead and thousands homeless (Johnson \& Jacobs, 2012: 330).

\section{Framing the informal economy within sustainable livelihoods approach}

The economy consists of two sectors known as the formal sector and the informal sector. The main differentiating characteristic between these two sectors is their relations with the monitoring mechanisms and policies in a country (Philip, 2010). This article looks at the informal economic sector and the impact it has on poverty eradication and job creation. The term "informal sector" was first coined by Keith Hart in his study of the economic activities of the urban economy of Accra, Ghana, in 1973. Hart used the term to refer to the low income activities of the urban poor who could not find wage employment. The term was subsequently adopted and popularised by the International Labour Organisation (ILO) as "informal economy" (Weigo, 2012: 3).

In the developing nations, the informal sector forms part of the social security for most of the poor. Chant (2002: 209) points out that since the 1980s, most of the growth in informal employment has been forced by recession and neo-liberal economic restructuring. Furthermore, Chant \& Mcllwaine (1995) state that people have been pushed into informal employment through cut-backs in public employment, the closure of private firms and the increased tendency for formal employers to resort to sub-contracting arrangements. The informal economic sector could be part of the solution to provide and create jobs which government fails to create, yet it continues to regulate the sector through licences, taxes and other regulations. Brown \& Scharfft (2011: 156) add that informal economic activities entail self-provisioning (gardening, fishing, gathering fruits and vegetables) and inter-household exchanges of a wide range of goods and services such as food stuffs, repair services, and/or household maintenance. In the light of socio-economic hardships, the sector could also be a solution to decent and sustainable jobs. The informal sector is a reality in Africa and a vast, largely unutilised resource. In his study, De Soto (1989) argues that if the informal sector is legalised the well-being of many poor people in Lima, Peru, could be improved through housing. He asserts that it could help the poor to transcend their state of impoverishment. Potts (2008: 151) states that to understand the informal sector one has to look at its dualistic interpretation. Meagher (2001: 54) states that the standard dualistic framework has been the bane of informal economy research since its inception. Meagher (1995) blames Structural Adjustment Programmes (SAPs) in Africa for undermining informal enterprises and economic activities. He further argues that the informal sectors opened up by national processes favour richer entrepreneurs or enterprises from the main cities. In South Africa, government has created policies that acknowledge the pivotal role informal sector can play in growing the economy and in providing a safety net for the poor and indigent. However, government has failed to protect and support the informal sector within the competitive environment dominated by big businesses. Government provides gaps in the legal structures permitting stronger economies to exploit the informal labour. Meagher (1995: 277) argues that permitting the informal sector to operate generates new inequalities and disempowerment in the informal sector. 
Over the years, the nature and importance of the informal economy has been understood allowing for the formulation of more contemporary definitions. One of these contemporary definitions is that the informal economy is a group of "informal self-owned enterprises", which may employ family workers, and other employees on an occasional basis (Devey, Skinner \& Valodia, 2003: 50). For operational purposes, and depending on national circumstances, this segment comprises either self-owned enterprises or only those which are not registered under specific forms of national legislation (factories or commercial acts, tax and social security laws, professional groups, regulatory or similar actions, laws or regulations established by national legislative bodies) (Devey et al., 2003: 50). The informal economy consists of non-registered employees who work in small-sized enterprises. What makes the informal economy interesting is its elusive character, where some economic activities in the informal economy are legal and others illegal. Also, nature and operational methods of the business establishment creates difficulties in regulating this sector and is viewed as being problematic by the state. Its fluidity and ability to pop-up anywhere anytime, notwithstanding differences in ethnicities and cultural backgrounds, gives the informal economy an identity which allows the sector to adapt in almost all contexts. For Smith (1989: 3 ), this character could probably be the secret recipe to its growth and sustainability.

Figure 1: The Sustainable Livelihoods Framework

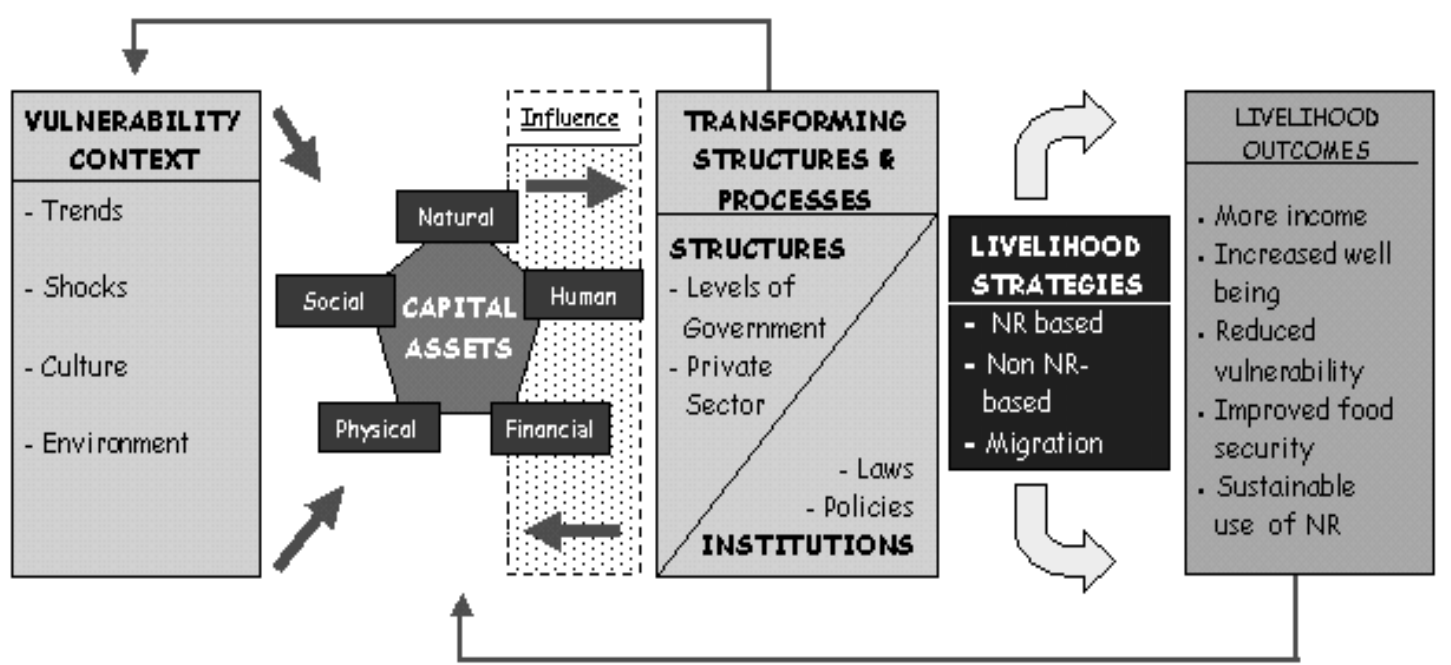

Source: Adapted from DIFID, 2002, www.livelihoods.org [Accessed 19 August 2015].

This article is grounded in sustainable livelihoods framework within which entrepreneurship activities take place, and potential to provide the poor and vulnerable with safety net is realistic. The concept of sustainable livelihoods originated from research conducted at the Institute of Development Studies at Sussex University (IDS), UK. Chambers \& Conway (1992: 6) in particular, define livelihood as "the capabilities, assets (stores, resources, claims and access) and activities required to secure means of living. This approach frames livelihoods in terms of people's resources or assets, their vulnerabilities, commodities or services they require and activities or strategies they adopt (Hussein, 2002). In addition, Arshley \& Carney (1996: 6) define sustainable livelihood as a "way of thinking about the objectives, scope and priorities for development in order to enhance progress in poverty elimination". The sustainable livelihood approach is premised on the strength of a theoretical foundation anchored on people-centred and asset-based approach to development (Barrett et al., 2008). Carney (1998: 8) associates livelihood with people-centred and asset-based approaches, 
which "comprising the capabilities and assets (including both material and social resources) and activities required for a means of living". According to Hussein (2002: 14), a livelihood is sustainable when it can cope with and recover from stresses and shocks as well as maintain or enhance its capabilities and assets both now and in the future, while not undermining the natural resource base. There are five basic assets or capitals namely: human, natural, social, financial and physical capital involved in the activities of the sustainable livelihood framework.

In essence, the sustainable livelihood approach is a framework through which people particularly the poor are able to use their assets in order to enhance their lives. This framework groups assets into five categories or resources such as human capital, natural capital, social capital, financial capital and physical capital (DFID, 2002). In order to survive both local and foreign nationals have to depend on capital. For example, skills and knowledge acquired by individuals are put to better use, especially in growing their businesses while social and financial capital can be used to expand and sustain their enterprises. Thus, the optimal utilization of these capitals could help in reducing vulnerabilities and further increase self-reliance.

\section{Research methods}

In this article, participant observation, semi-structured interviews and document analysis were chosen as the research techniques to obtain relevant data. The sample consisted of 20 participants whose ages ranged from 18-40. Fifteen (15) participants were randomly selected through snow ball sampling technique 5 were officials especially those who were involved in organising the anti-xenophobic march and assisting foreign nationals affected by xenophobic attacks. The sample included eight (8) men and seven (7) women; and, the five (5) officials were drawn from departments of Safety and Security, Social Development, Community Participation \& Action Unit, Home Affairs, Transport and Health. The sample was limited to foreign nationals especially those from Nigeria, Malawi, Congo, Zimbabwe residing in Durban. The interviewees' experiences contributed to a more balanced and complete understanding of the issues and forces behind xenophobic or Afrophobic hatred and attacks. The interviews for this research were conducted in August and took two weekends, from the 21-23 and 28-30 August 2015. A workshop at West Street was chosen as the central place for conducting interviews and engaging the participants whereas municipal officials preferred their offices as the meeting place.

Since most of the participations could not communicate in English, some of the interviews were narrated in French and translated into English. Post graduate students who are French speaking were helpful in the translations. For analysis purposes, direct quotes from the interviews were incorporated to highlight and enable a deep understanding of some of the key issues on the impact of xenophobic attacks on the informal economy. This sample was targeted at foreign entrepreneurs and hawkers involved in informal economic sector. The interviews were conducted along the lines of the following questions: (1) What is your understanding of xenophobia? (2) What causes xenophobia? (3) Who was behind xenophobic attacks and why? (4) How were you affected by xenophobic attacks? (5) Do you feel safe operating here? (6) How did xenophobic attacks affect your business? (7) What are the social effects of xenophobic attacks? (8) Is there a reason for attacking foreigners? (9) Do you think that retaliation would solve socio-economic problems? (10) Did you lose any stock after the attacks? (11) What were the financial loses? (12) What was the role of government in either 
stopping or perpetuating xenophobia? (13) What strategies were used by government to assist the victims of xenophobic attacks? (14) Were these strategies effective and if so how? (15) How can xenophobia be stopped?

\section{Findings and analysis}

\section{Securing people's livelihoods through informal economy}

The informal sector remains a predominant source of livelihood for both South Africans and non-South Africans. Thus, Sociologists associate informal sector with informal economy underpinned by activities such as unpaid domestic work, consumption work, non-market productive labour, and community service work. A female informant revealed that:

"As a foreigner, socio-economic survival is the first priority and regardless of their status and qualifications in the countries of origin, most of the foreigners seized both educational and employment opportunities in their disposal. Despite all impediments we come across especially in securing formal jobs, preference and hard work pay in the end" (Interviewee No 4, Workshop, 22 August 2015).

This was confirmed by a 29 year old male said that:

"The structural barriers for foreign nationals to get jobs has created an attitude
amongst
South Africans to believe that all foreigner are stupid, are uneducated bence they are here

to take our jobs" (Interviewee No 1, Workshop, 21 August 2015).

This myth and stereotype was dismissed by an interviewee who confidently revealed that:

"In my country Burundi, I am a qualified lawyer with one year of practice and due to political conflicts I had to run for life after my younger brother was killed. Upon my arrival in 2009, I worked as a security for many companies and it was only in 2013 that I managed to save cousin enough to buy a container to establish three solons" (Interviewee No 3, Workshop, 22 August 2015).

Evidence from the interviews revealed that the majority of non-south Africans are eking a living from activities such as hair salons and barber shops, clothing industry, nail bars, grocery, cell phone and computer stores specializing in selling and repairs. The situation facing the foreigners was described by a Nigerian national as:

"a double edged sword whereby foreigners are perceived as assets to the South African economy while on the other hand they are despised as either makwerekwere or aliens" (Interviewee No 9, Workshop, 23 August 2015).

The term "makwerekwere" is derogatory, commonly used by South African nationals to describe those who cannot speak local languages or dialects (Oucho, 2006: 61). The respondents in interviews attested that for the informal economy to survive the socioeconomic storm amidst political instability, it require citizen-based immigration laws committed to African regional integration based on pan Africanism and African Renaissance as explicated by African leaders. In order to improve the slow economic progress and marginalisation, Binns et al. (2012: 239) argue that new regional development strategies and policies could provide socio-economic impetus and further advance cross-border linkages 
within the continent. Thus, regional development integration could be pursued to achieve collective self-reliant development, facilitating trade, social, cultural and economic exchange, peacekeeping and the overall promotion of pan-Africanism (Binns et al., 2012). Operating on the principle that "beggars cannot be choosers", African immigrants managed to optimally utilize their natural abilities and talents to earn a living.

Central to the informal economy is the utilization of skills and talents for living, in this regards Kertzer (2012: 117) argues that "let people themselves also come up with their talents ... helping people to use their own abilities to do things for themselves". For the immigrants, informal economic activities are compulsory for socio-economic survival; hence, Oberhauser \& Pratt (2004 in Pratt, 2006: 84) argue that informal activities have provided alternative income generating activities for the unemployed, while also enabling them to cope with poverty and local community problems. A 25 year old mechanic from Congo, in narrating his history, said that:

"I was taught to repair cars by my senior brother, I never went to school and due to perseverance today I cannot sleep hungry, it based on leant apprenticeship that most of us regarded as foreigners are able to survive economically. Through the little we generate daily we are able to put food on the table and pay for accommodation" (Interviewee No 34, Workshop, 22 August 2015).

Evidence from this research pointed out that non-South Africans in South Africa endure unbearable criminalisation with derogatory names such as bogus refugees; however, their exposure has taught them to create something out of nothing (also see Amtaika, 2013).

In this context, Binns et al. (2012: 505) opine that African immigrants tended to fill the jobs that nationals reject, with a view to saving enough money to return home and start up business. Eking from the informal sector is hard. A Ghanaian clothing boutique owner conceded that:

"The secret to success in this sector is for one to be hands on and mastering the skills including knowing where to buy fashionable clothes for the customers. Thus operating from the position of power and human capability one is able to provide necessary support and guidance for the few people employed" (Interviewee No 13, Workshop, 28 August 2015).

For the optimal use of assets, skills and talents, Weavind (2012: 1) believes that people should create their own jobs hence he argues that "entrepreneurs should be encouraged to start businesses that can generate employment and grow the economy". This entails transforming assets and people's resources into productive livelihoods in dealing with socioeconomic vulnerabilities exacerbated by slow economic growth and the exclusion of the poor and foreigners.

\section{Impact of xenophobia on the informal economy}

\section{Socio-psychological dimension of xenophobia}

Economic challenges such as poverty and unemployment have been cited as the driving force behind xenophobia and xenophobic or Afrophobic attacks and violence (Amtaika, 2013; 
Akinola, 2014). The economic dominance has perpetuated a wide spread perception that misplace the social dimension as non-issue in the xenophobia equation. The sociopsychological dimension of xenophobia has a historical cleavage in South Africa and this could be traced back to the apartheid era. Apartheid was based on racial and ethnic discrimination and divisions; and, as such South Africans were not only divided according to their different races but also partitioned along ethnicity and religious lines. Thus, the institutionalisation of the apartheid system, according to Van der Zee (2007: 7), engenders the sense of alienation and marginalisation that ultimately led to social conflict. A participant highlighted that:

\section{"Internal socio-economic deficiencies degenerate beyond alienating and marginalising those \\ called outsiders or makwerekwere into physical hard portrayed through xenophobic attacks"}

(Interviewee No 12, Workshop, 28 August 2015).

In this context, Terreblance (2012: 79) argues that due to the legacy of apartheid, many Africans remain victims of colonial and apartheid exploitation and repression, on one hand, and it nurtured a sense of solidarity and togetherness, on the other hand. An official from the Department of Social Development expressed that:

"in the prevalent of severe poverty, locals become vulnerable that they are capable of doing anything to survive including justification to kill or cause bodily harm to other people irrespective whether one is a foreigner or fellow South African" (Interviewee No 15, Departmental office, 28 August 2015).

Participants were in unison in condemning the killings and physical attacks directed at other African nationals on the basis of petty reasons such as "they are taking our women, they are drug dealers" (Interviewee No 5, Workshop, 22 August 2015). They pitied South Africans especially those who have limited knowledge of Africa's history and its socio-economic and political challenges. Common knowledge to this situation is the political instability and economic uncertainty engulfing the African continent. Consequently, the hostile environment has been instrumental in displacing people to the neighbouring nations and even overseas, as refugees. The xenophobic attacks orchestrated by locals since 2008 and renewed in April-May 2015, has painted a negative image contrary to the commitment South Africa has made through bodies such as the human rights commission of the United Nations. It could be argued that persistence of xenophobia or Afrophobia is a betrayal of South Africa's commitment and quest to create non-racialism, non-sexism and democratic society stipulated in the Preamble of the Constitution (RSA, 1996: 1). Xenophobia dislocated foreign nationals not only from their source of livelihood (businesses) but it has also isolated them from their business partners and friends some of whom happen to be South Africans. The following comments from a Malawian national attest to this:

"Placing us at the camps in Isipingo and Chatsworth provided a temporary shelter including basic necessities such as food, clothing, but did not dispel the fear we have for our lives" (Interviewee No 12, Workshop, 28 August 2015).

A Nigerian national acknowledged the support received from the government and NGOs as well as private companies, and had this to say: 
"The hospitality extended by the South African government and the eThekwini municipality was enormous, however such support generate further conflict especially when the locals blamed government for prioritising foreigners over their citizens" (Interviewee No 6, Workshop, 23 August 2015).

Evidence from this research suggests that social exclusion and marginalisation of migrants are orchestrated by locals and government by denying the existence of xenophobia or Afrophobia. For Fetzer (2000 cited in Akinola, 2014: 58), xenophobia above all undermines social cohesion, peaceful co-existence, good governance and observance of human rights. In the post-apartheid era, attempts to reconstruct and develop South Africa find expression through the notion of "rainbow nation" as advocated by Anglican Archbishop Desmond Tutu and the late president Nelson Mandela (in Mashele \& Qobo, 2014: 65). A "rainbow nation" has become a measure to evaluate how well do people jell together in forging a united and democratic society. For this clarion call of "rainbow nation" (Cebekhulu, 2013: 19) to be a uniting force, it should transcend racial and ethnic divisions to engender "unity in diversity" (de Jager, 2013: 147) and embrace continental unity as espoused by Kwame Nkrumah in his book Africa Must Unite. Under imperialism, colonialism and apartheid, Africans were forced to be foreigners in their own continent but now they are turning against each other, yet the only way forward to build a strong continent is for all Africans to unite against colonial and neo-colonial mentality. Nkrumah (1963: 174) suggests that neo-colonialism “... creates client states, independent in the name but in point of fact pawns of the very colonial power which is supposed to have given them independence". The acts of xenophobic intolerance and attacks made a mockery of the notion of Africa for Africans.

\section{Economic dimension of xenophobia}

More often, economics dominate most of the discussions pertaining to xenophobia taking place in South Africa. As the strongest economy in the continent, South Africa has its drawbacks especially in becoming the economic and political haven for non-South Africans faced by socio-economic and political hardships and oppression (Ramphele, 2008: 288). Scrambling for limited economic resources has partly contributed to the wide-spread xenophobic and Afrophobic attacks. Thus, the hatred and anger against non-South Africans by locals since the dawn of democracy has degenerated into jealousy hence the physical attacks and fatalities (Masuva, 2014, Akinola, 2014). Evidence from the research found that most of the reasons cited for targeting "foreigners" are captured in the following quote:

'They are taking our business', their businesses are successful because they are involved in drugs', their stuff is cheap hence people buy from foreign shops than us" (Interviewee No 10, Workshop, 28 August 2015).

Considering that xenophobic attacks were justified on economic grounds, foreign nationals were accused by locals for "competing with them for jobs, housing and other resources which the locals feel they are entitled to" (Masuva, 2014: 387). These articulations underlie unhealthy competition between the locals and non-South Africans. The research conducted by Human Sciences Research Council (2012: 31) shares similar findings that in most cases the resistance stage by locals against immigrants is perpetuated due to competition on local economics and public resources. These economic citations did not only sustain xenophobic or Afrophobic attacks, they have also fuelled the suspicion that most of the businesses run by 
non-Africans, especially black Africans, are shoddy and are funded through drug dealing. A counter view was shared by one of the female respondents who said:

"the reality stares us in the face in that businesses owned by so called 'makwerekwere' are run relatively well compared to those by locals, despite being affordable and accompanied by sound customer care based on human relationship values and principles" (Interviewee No 2, Workshop, 22 August 2015).

An official from the Department of Human Settlement indicated that:

"locals are often frustrated by their limited stocks compare to with the non-South Africans who do bulk buying and, networking and expanding their networks is central to their success" (Interviewee No 12, Departmental office, 28 August 2015).

Failure to compete at this level culminate into local businesses closing down with the option of renting them out to foreigners. In this instance, an official from Community Participation and Action Unity (CPAU) revealed that:

\section{"Most of the foreign business owners buy their stock at Favour Wholesaler. Importantly, the Wholesaler was helpful especially in providing stock on credit mainly for foreign shops after their small businesses were looted during the xenophobia upheaval" (Interviewee No 11, Workshop, 28 August 2015).}

In the Durban CBD, the expression of xenophobia gave rise to anger and jealousy which resulted into shops and stalls belonging to foreign nationals being vandalised and their stock being looted. During this rampage, locals voiced their dissatisfaction against the municipality for supporting the businesses run by non-South Africans and not by locals. The mere fact that most of the non-South Africans are successful has raised eye brows, especially from the locals who concluded that foreigners are being favoured when it comes to business support. Kalitanyi \& Visser (2010: 376) argue that the success behind immigrants' businesses is due to the effective application of their entrepreneurial skills in both establishing small businesses and employing workers. Given the prevalence of poverty and unemployment and income inequality, Petrin (1994: 7) and Khawar (2007: 3) argue that entrepreneurship is not instrumental in widening the economic base and grow the economy, but that it can also be a tool for strengthening the process of wealth creation. In this respect, government in general and eThekwini municipality in particular were accused by non-South Africans for failure to create jobs so that at the end the locals should not entertain the attitude that immigrants are in South Africa solely to take their jobs. For Meyer \& Venter (2013: 91), the state's failure to fulfil its developmental mandate coincide with its failure to create conducive and enabling environment to sustain small businesses and further forge employment opportunities, especially for the poor and those economically excluded and marginalised people. This failure could be validated by the amount of money which small business owners pay to operate in places such as the Workshop in West Street. For example, it was revealed during the interviews that for a licence, each person pays R500, for security it is R210, R240 for storage and R800 for the trolley boy per month. A total monthly amount paid by each person is R1 750 , excludes remuneration for the assistants.

\section{Socio-Political dimension of xenophobia}

Xenophobic or Afrophobic attacks did not only dislocate people, economically, but businesses belonging to foreign national were vandalised and their stock looted. Consequently, these acts created political instability where municipality and government were blamed for not doing enough to curb the plague of xenophobia or Afrophobia (Bekker, 2008: 136). The 
South African immigration policies were blamed for perpetuating violent attacks on foreigners, hence the naming of immigrants as "economic migrants" or "bogus refugees" or "aliens" (Nugent, 2012: 503, 505). These names are reflective of how narrow-minded, government and its machinery can be in dealing with a sensitive matter like xenophobia. The attacks were economically triggered by local employers employing foreign nationals while the local employees were on strike demanding salary increment at Umnyani Mall situated at Umlazi Township. The utterances by Zulu King Goodwill Zwelethini was interpreted by mainly unemployed locals as the political passport to ostracise and chase away non-South Africans. A Senegalese national:

"blamed the King as the main cause and perpetuator of xenophobia attacks and its escalation in Durban and its surrounding townships" (Interviewee No 14, Workshop, 28 August 2015).

A lesson to be drawn in this scenario is that leadership either democratically elected or traditional should take responsibility of what they say and do.

Xenophobic attacks were sustained through mob-psychology where rational thinking about the real causes of the anger and hatred dissipated. Instead, most of the foreigners were chased around the Durban CDB regardless of their immigration status. The failure by the Department of Home Affairs and other law enforcement agencies to reinforce immigration policies paved way for locals and foreigner to embark on criminal activities. Foreign nationals in this case became the scapegoat for the socio-economic plight and deprivation. The attacks were not only xenophobic but they also had criminal elements. Most participants accused government of orchestrating alienation and marginalisation of foreigners by applying "draconian measures" aimed at controlling refugees and asylum seekers; hence, Akinola (2014: 64) accuses the South African state of perpetrating extreme hostility and structural hatred towards non-nationals. In this regard, Ramphele (2008: 289) points out that with the persistent weaknesses in Home Affairs, South Africa runs the risks of being labelled as a violator of the human rights of the many refugees and as such failing to protect foreign nationals in terms of obligations under United Nations treaties. Politicians and officials continue to deny xenophobia and blame attacks on criminal elements. A municipal official revealed that:

"stall owners pay R740. 00 (56 USD) a month to the municipality which provides them with licence, space and warehouse space for their goods (Interviewee No 10, Municipal office, 28 August 2015).

A female Congolese expressed her frustration that:

"those foreigners working in the hair salons are harassed daily by Metro police seeking. bribes and at times soliciting sexual favours, and the private security are on our case for no apparent reason (Interviewee No 18, Workshop, 30 August 2015).

Another hairdressing specialist respondent said:

"at the Workshop, we have made arrangements that on a daily basis we pay security guards an amount of R210, 00 per month for security and protection against local criminals and robbers (Interviewee No 9, Workshop, 23 August 2015).

Thus the failure to restore stability engenders lawlessness whereby locals, including the passer-by people, get to be preoccupied with looting of stock and destroying stalls belonging to the foreigners. 


\section{Political economy underpinning xenophobia and xenophobic attacks}

Xenophobia can be understood and analysed by using political economy framework. Stanilam (1985: 6) defines political economy as how politics determine aspects of the economy as well as the dynamics interaction between the two forces. Within the African continent, the adoption of democracy as the governance system was not only underpinned by autocratic leadership, but it was accompanied by declining economy. A Ghanaian national blamed poor and selfish African leaders for the plight that continue to rip Africa apart saying that;

"Once Africans leaders are elected into the position of power they either don't want to
step down or imposed themselves through forming militia groups causing civil wars and
political instability" (Interviewee No 15, Workshop, 29 August 2015).

With this mind, autocratic behaviour of African leaders accompanied by harassment and imprisonment saw most of inhabitants being dislocated as refugees, especially to those countries which are relatively peaceful and their economy stable. Upon arrival, most people were shocked to discover that the land they had envisaged was unreal. Immigration results into the diaspora communities either within Africa itself or in the Western became home for many displaced African nationals, especially from Zimbabwe, Somalia, Rwanda, Ethiopia, Congo and Nigeria. Consequently, these migratory patterns caused "brain drain". Nugent (2012: 506) states that brain drain is persistent in robbing and disadvantaging Africa of foreign investment and remittances. He went further to highlight that the refusal by many African states to recognise dual nationality resulted into the situation whereby citizens are turned into foreigners despite their self-determination and continuing support for kith and kin (Nugent, 2012). In Africa, political instability is, according to Handelman (1996: 7), underpinned severely by political underdevelopment than by social and economic underdevelopment. The genuine integration of South Africa into Africa is essential for building and fostering patriotism and trust of all the African people. In this regard, Maphunye et al. (2014: 23) argues that South Africa's independence will be meaningless unless the country's democratic trajectory is intertwined with Africa's genuine socio-economic and political freedom. A Zimbabwean interviewee opined that:

\section{"Unless the government deals with the poverty especially the unemployment situation, xenophobia will never end in South Africa rather more people foreigners will die and continue to be harassed, intimidated and face deportation (Interviewee No 11, Workshop, 28 August 2015).}

The political economy is a splinter approach in terms of understanding the exacerbation of xenophobic or Afrophobic attacks on foreign nationals. Democracy according to Terreblanche (2012: 37), represents the political side of the dual system underpinned by capitalism, which represents the economic side. Thus the strength and sustainability of the system of democratic capitalism depends on the mutual interdependence of democracy and capitalism (Terreblanche, 2012: 38). Politically, South Africa's quest to build a rainbow nation was frustrated by the legacy of apartheid with immigration policies that still promote exclusionary laws and treat fellow Africans as aliens. Peberdy (2009: 147) attests to the discriminatory policies by tracing the isolation and tension way back from the 1970s to the early 1990s which led to the reduction in the number of southern Africans living in the Republic. Despite some changes in the immigration policies since 1994, the legacy of apartheid policies continues to keep South Africa divided along racial and ethnic lines. Although some of the locals interviewed agreed that attacking non-South Africans and looting their stocks is not the solution to xenophobia, an Ethiopian migrant warns that: 


\section{"Government should stop paying lip-service to its immigration policies and start to recommit itself to reintegration of foreign nationals" (Interviewee No 20, Workshop, 30 August 2015).}

The harsh or linear policies regulating the movement of foreign nationals have been accused of causing "social and political exclusion" (Neocosmos, 2010: 13). Masuva (2014: 377) concurs with Neocosmos that xenophobia is "politics of exclusion"; and, the state is blamed for the marginalisation of migrants through passing restrictive policies and practices. Borrowing from Fanon's (1963) expression of internalisation of oppression, it appears as if South Africans are the victims of the oppressive and racist apartheid regime; and, amidst the prevalent socio-economic crisis, non-South Africans tend to become "secondary victims" of xenophobia or Afrophobia. The failure to balance the political governance system and economic approaches adopted since 1994, has led to the escalation of poverty, unemployment and inequality (Terreblance, 2012). The socio-economic exclusion and marginalisation denied locals their economic citizenship; hence, Ramphele (2008: 162) argues that many refugees with high-level skills are being identified and encouraged to help the struggling public service.

\section{Conclusion}

In this article, the notion of xenophobia or Afrophobia and its impact on the operations of the informal economy was interrogated within the context of sustainable livelihood framework. Economic sectors in the midst of socio-economic hardships became the last resort, not only for locals but also for non-South Africans. The emergence of xenophobic or Afrophobic attacks in the month of April 2015, saw the streets of Durban being deserted and foreigners under siege. Shops and stalls owned by non-South Africans were targeted, looted and their businesses vandalised under the pretence that "makwerekwere" were taking the locals' jobs. This article revealed that unlike sporadic xenophobic attacks in the previous years, those staged in April were structurally organised with transportation for attackers to hunt for foreigners within the Durban CBD and the surrounding townships.

Socio-economic and political implications as discussed in this article are enormous, hence both locals and non-South Africans were affected. Socially, fear planted through the scourge of xenophobia overwhelmed the city of Durban accompanied by the decline in both the formal and informal sector, with the later bearing the most brunt. On the one hand, the city was turned into a battle field whereby Afro-hatred was perpetuated with the intention of causing bodily harm and making deportation threats. On the other hand, the closing of small businesses belonging to foreigners meant that locals were unable to access affordable goods and services. In conclusion, the article argued that both local and foreigners are victims of a weak and irresponsive political economy; yet, for South Africa to eradicate xenophobia and its unintended consequences, a comprehensive strategy is imperative to boost socio-economic development within the SADC region and in Africa at large.

\section{References}

Akinola, A.O. 2014. South Africa and the two faces of xenophobia: A critical reflection. Africa Peace and Conflict Journal, 7(1): 56-67. 
Amtaika, A.D. 2013. Local Government in South Africa since: Leadership, Democracy, Development and Service Delivery in a Post-Apartheid Era. Durham: Carolina Academic Press.

Ashley, C. \& Carney, D. 1996. Sustainable Liveliboods: Lessons from Early Experience. London:

Russell Press Ltd.

Barrett, C.B., Carter, M.R. \& Little, P.D. 2008. Understanding and Reducing Persistent Poverty in Africa. Abingdon: Routledge.

Bekker, S. 2010. Explaining violence against foreigners and strangers in urban South Africa: Outbursts during May and June 2008. In Yusuf, A.A (ed). The African Yearbook of International Law. Leiden: Brill Publishers.

Binns, T., Dixon, A. \& Nel, E. 2012. Africa Diversity and Development. London/New York: Routledge.

Brown, D.L. \& Scharfft, K.A. 2011. Rural People and Communities in the 21 ${ }^{\text {st }}$ Century: Resilience E Transformation. Cambridge: Polity Press.

Carney, D. 1998. Implementing the Sustainable Rural Liveliboods: What Contributions can we Make? London: Department for International Development.

Cebekhulu, E. 2013. Umblaba Uyablaba: The World is Thorny! Wandsbeck: Reach Publishers.

Chambers, R. \& Conway, G. 1992. Sustainable rural livelihoods practical concepts for the $21^{\text {st }}$ Century, IDS Discussion Paper 296. Brighton: Institute of Development Studies.

Chant, S. \& Mcllwaine, C. 1995. Women of Lesser Cost: Female Labour, Foreign Exchange and Philippine Development. London: Pluto.

Chant, S, 2002. The informal sector and employment. In Desai, V. \& Potter, R.B. (eds.). The Companion to Development Studies. London: Arnold.

Crowther, J. \& Martin, I. 2005. Learning Democracy and Activating Citizens: A Role for Universities. In Wildemeersch, D., Stroobants, V. \& Bron Jr, M. (eds.). Active Citizenship and Multiple Identities in Europe: A Learning Outlook. Berlin/New York: Peter Lang.

De Jager, N. 2013. South Africa: A Democracy in the balance. In De Jager, N. \& Du Toit, P. (eds.). Friend or Foe? Dominant Party Systems in Southern Africa: Insights from the Developing World. Tokyo/New York: United Nations University Press/Konrad Adenauer Stiftung.

De Sotho, F. 1989. The Other Path: The Invisible Revolution in the Third World. New York: Harper \& Row.

DFID, 2002. Gender Manual: A practical guide for development policy makers and practitioners, by Helen Derbyshire, Social Development Division, London: DFID

Evert, D. 2011. Xenophobia, state and society in South Africa, 2008-2010. Politikon: South African Journal of Political Studies, 38(1): 7-36.

Fanon, F. 1963. The Wretched of the Earth. London: Penguin Books. 
Feberdy, S. 2009. Selecting Immigrants: National Identity and South Africa's Immigration Policies, 1910-2008. Johannesburg: Wits University Press.

Handelman, H. 1996. The Challenge of Third World Development. New Jersey: Prentice-Hall, Inc.

Hussein, K. 2002. Livelihood Approaches Compared: A Multi-agency Review of Current Practice. London: DFID.

Johnson, K \& Jacobs, S (eds.). 2012. Encyclopaedia of South Africa. Scottville: University of KwaZulu-Natal.

Kalitanyi, V. \& Visser, K. 2010. African immigrants in South Africa: Job takers or job creators? SAJEMS, 13(4): 376-390.

Kreitzer, L. 2012. Social Work in Africa: Exploring Culturally Relevant Education and Practice in Ghana. Calgary-Alberta: University of Calgary Press.

Laundau, L. 2005. Transplants and transients: Nativism, nationalism, and migration in inner-city Johannesburg. Migration Working Paper Series No 19. Pretoria: Forced Migration Studies Programme. http://wwww.migration.org.za

Maphunye, K., Kibuka-Sebitosi, E. \& Moagi, A.L. 2014. South Africa Twenty Years into Democracy: The March to the 2014 Elections. Pretoria: WIPHOLD-Brigalia Bam Chair in Electoral Democracy in Africa.

Matsinhe, D.M. 2011. Africa's fear of itself: The ideology of makwerekwere in South Africa. Third World Quarterly, 32(2): 295-313.

Mashele, P. \& Qobo, M. 2014. The Fall of the ANC: What Next? Johannesburg: Picador Africa.

Musuva, C. 2014. The Politics of Xenophobia in South Africa: Marginalisation of African migrants by the State. In Ewusi, S.K. \& Butera, J.B. (eds.). Beyond State-Building: Confronting Africa's Governance and Socio-economic Challenges in the $21^{\text {st }}$ Century. Addis Ababa: University for Peace Africa Programme.

Meagher, K. 1995. Crisis, infomalisation and the urban informal sector in Sub-Saharan Africa. Development and Change, 6(2): 259-84.

Meyer, D.F. \& Venter, A. 2013. Challenges and solutions for Local Economic Development (LED) Municipal institutional arrangements: The case of the Northern Free State. Administratio Publica, 21(4): 91-113.

Mngxitama, A. 2008. We are not all like that: Race, class and nation after apartheid. In Hassin, S., Kupe, T. \& Worby, E. (eds.). Go Home or Die Here: Violence, Xenophobia and the Reinvention of Difference in South Africa. Johannesburg: Wits University Press.

Moosa, V.M. 2008. Celebrating the 75th Anniversary of the ANC. Speech by Mohammed Valli Moosa on 08 January 2008, Soweto.

Neocosmos, M. 2010. From Foreign Natives to Native Foreigners: Explaining Xenophobia in Post-Apartheid South Africa - Citizenship and Nationalism, Identity and Politics. Dakar: CODESA.

Nkrumah, K. 1963. Africa Must Unite. London: Panaf Books.

Nugent, P. 2012. Africa Since Independence, $2^{\text {nd }}$ edn. London: Palgrave Macmillan. 
Nyamnjoh, F.B. 2006. Insider and Outsiders: Citizenship and Xenophobia in Contemporary Southern Africa. Dakar: CODESA.

Petkou, C.L. 2005. The development of ethnic minorities: A case study of West Africans in South Africa. PhD Thesis submitted to the University of the Witwatersrand, Johannesburg.

Petrin, T. 1994. Entrepreneurship as an economic force in rural development. Keynote paper presented at the Seventh FAO/REU International Rural Development Summer School, Herrsching, Germany, 08-14 September 1994.

Potts, D. 2008. The Urban informal sector in Sub-Saharan Africa: From bad to good (and back again). Development Southern Africa, 25(2):150-167.

Pratt, A.D. 2006. Women's Livelihood Strategies in Diverse Contexts: Constructing Feminist Topographies in Appalachia and South Africa. A Doctoral Thesis submitted to Ebberly College of Arts and Sciences, West Virginia University, West Virginia University, Morgantown.

Oucho, J.O. 2006. Cross-border migration and regional initiatives in managing migration in Southern Africa. In Kok, P., Gelderblom, D., Oucho, J.O. \& van Zyl, J. (eds.). Migration in South and Southern Africa: Dynamics and Determinants. Cape Town: HSRC Press.

Ramphele, M. 2008. Laying Ghosts to Rest: Dilemmas of the Transformation in South Africa. Cape Town: Tafelberg.

Republic of South Africa (RSA), 1996. Constitution of the Republic of South Africa (No, 108 of 1996). Pretoria: Government Printers.

Sichone, O. 2008. Xenophobia. In Shepherd, N. \& Robins, S. (eds.). New Southern African Keywords. Jacana/Johannesburg: Ohio University Press/Athens.

Smith, J.D. 1987. Measuring the Informal Economy. Annals of the American Academy of Political and Social Science, 493: 83-99.

Stanilam, M. 1985. What is Political Economy? New Haven: Yale University Press.

Van der Zee, D. 2007. From Intellect to Intelligence: A Radical Natural Human Alternative. Pretoria: Griffel Media.

Terreblance, S. 2012. Lost in Transformation: South Africa's Search for a New Future Since 1986. Johannesburg: KMM Review Publishing Company.

Weavind, T. 2012. Creating your own job. Sunday Times, 12 August 2012. p.1.

WEIGA, 2012. The Informal Economy: Definitions, Theories and Policies. http://led.co.za/topic/informal-economy [Accessed: 19 August 2015]. 